\title{
A preliminary study to determine optimal feed rations for Cyprinus carpio L. $\times$ Carassius auratus L. hybrids reared in cages in spent cooling water
}

\author{
Jacek Sadowski, Magdalena Wielopolska, Marek Bartłomiejczyk, Mirosław Półgęsek, \\ Ewelina Giedziun
}

Received - 23 October 2018/Accepted - 20 December 2019. Published online: 31 December 2019; @Inland Fisheries Institute in Olsztyn, Poland Citation: Sadowski J., Wielopolska M., Bartłomiejczyk M., Półgęsek M., Giedziun E. 2019 - A preliminary study to determine optimal feed rations for Cyprinus carpio L. $\times$ Carassius auratus L. hybrids reared in cages in spent cooling water - Fish. Aquat. Life 27: 190-197

\begin{abstract}
This study was conducted to investigate the effects of feeding rations on growth, feed utilization, and proximate composition of Cyprinus carpio $\times$ Carassius auratus hybrids reared in cages located in power station cooling waters. The study was conducted at the Fisheries Experimental Station of the Department Aquaculture of West Pomeranian University of Technology in Szczecin located at the Dolna Odra Power Plant. The studies used the carp feed Classic (30.6\% protein, $8.8 \%$ lipid, $47.5 \%$ carbohydrate, and $18.1 \mathrm{MJ} \mathrm{kg}^{-1}$ gross energy) in the following rations: $0.8 \%, 1.2 \%, 1.6 \%, 2.0 \%$, and $2.4 \%$ of fish metabolic weight. Each of the variants were tested for 140 days in triplicate at a density of 150 fish per cage. During the experiment, the water temperature ranged from 17.1 to $34.3^{\circ} \mathrm{C}, \mathrm{pH}$ was $7.5-9.0$, and oxygen was $2.8-12.6 \mathrm{mg} \mathrm{dm}^{-3}$. At the end of the study, the mean individual body weights of the hybrids ranged from 150 to $430 \mathrm{~g}$ and the FCR was from 1.44 to 2.32 . The optimal piecewise regression model rations were $1.4 \%$ of metabolic body weight.
\end{abstract}

Keywords: cooling water, optimal feeding ration, hybrid carp $\times$ goldfish

\footnotetext{
J. Sadowski [ఏ"], M. Wielopolska, M. Bartłomiejczyk, M. Półgęsek, E. Giedziun

West Pomeranian University of Technology in Szczecin, Faculty of Food Science and Fisheries, Department of Aquaculture

ul. K. Królewicza 4, 71-550 Szczecin, Poland

e-mail: jsadowski@zut.edu.pl.
}

\section{Introduction}

Long-term studies at the Fisheries Research Station in Nowe Czarnowo have focused on the usefulness of rearing over a dozen common aquaculture fish species in spent cooling water, including rainbow trout, Oncorhynchus mykiss (Walbaum) (Trzebiatowski et al. 1981), Nile tilapia, Oreochromis niloticus (L.) (Filipiak et al. 1995), African sharptooth catfish, Clarias gariepinus (Burchell) (Filipiak et al. 1995), wels catfish, Silurus glanis L. (Filipiak et al. 1997a, 1997c), Siberian sturgeon, Acipenser baerii Brandt (Filipiak et al. 1997b), and sterlet, Acipenser ruthenus L. (Sadowski et al. 2000b). However, the most comprehensively studied species is the common carp, Cyprinus carpio L., which has been subjected to many nutritional experiments (Filipiak et al. 1998a, 1998b, 1998c, 1999, Sadowski et al. 1998, 1999a, 1999b) High carp mortality has been noted since 2002. Initially, the causes were unknown, but Bergmann et al. (2006) discovered that the deaths were caused by the $\mathrm{Cy}-\mathrm{HV}_{3}$ virus, which causes the disease popularly known as koi herpesvirus (KHV), and researchers began seeking a solution for this problem. Introducing interspecific hybrids between 
Table 1

Experimental parameters for rearing $C$. carpio $\times$ C. auratus hybrids for 140 days in cages located in a power station spent cooling water canal

\begin{tabular}{llll}
\hline \hline Variant & $\begin{array}{l}\text { Metabolic feed ration } \\
\%\left(\mathrm{~g} / \mathrm{kg}^{0.8}\right)\end{array}$ & $\begin{array}{l}\text { Stocking } \\
\text { density }\end{array}$ & Replicates \\
\hline \hline CC1 & 0.8 & 150 & 3 \\
CC2 & 1.2 & 150 & 3 \\
CC3 & 1.6 & 150 & 3 \\
CC4 & 2.0 & 150 & 3 \\
CC5 & 2.4 & 150 & 3 \\
\hline \hline
\end{tabular}

the carp and other members of the family Cyprinidae was an option. Tests indicated that a fish species that could successfully replace carp rearing material in spent cooling water was a hybrid between the carp and the goldfish (Bergmann et al., 2010). Hendrick et al. (2006) obtained similar promising results reporting that the common carp $\mathrm{x}$ goldfish hybrid is more resistant than both species to $\mathrm{Cy}-\mathrm{HV}_{2}$ and $\mathrm{Cy}-\mathrm{HV}_{3}$. Therefore, a cycle of research was undertaken to develop rearing technology for this hybrid.

One of the key issues in fish rearing is determining optimal feed rations for particular environmental conditions. This problem of utilizing the so-called metabolic feed ration (feed dose understood as a percentage of the metabolic weight of fish) has been repeatedly studied in spent cooling water conditions (Filipiak et al. 1997a, 1997b, Sadowski 1998, Sadowski et al. 2000a). This problem is also fundamentally important for developing a technology for rearing the Cyprinus carpio $\times$ Carassius auratus hybrid. Therefore, the goal of the present study was to

Table 2

Proximate composition of the diet tested on $C$. carpio $\times C$. auratus hybrids reared in cages located in a power station spent cooling water canal

\begin{tabular}{ll}
\hline \hline Components & Composition \\
\hline \hline Crude protein (\%) & 30.59 \\
Lipids (\%) & 8.79 \\
Carbohydrates (\%) & 47.51 \\
Dry matter (\%) & 91.79 \\
Ash (\%) & 4.90 \\
Gross energy (MJ kg & -1 ) \\
\hline \hline
\end{tabular}

Carbohydrates - difference between dry matter and the sum of crude protein, lipids, and ash determine optimal feed rations for $C$. carpio $\times C$. auratus hybrid fry (age: $1+$ ) reared in summer in spent cooling water.

\section{Material and methods}

The study was conducted from May 7 to September 24 at the Fisheries Research Station (RSD) of the Department of Aquaculture, West Pomeranian University of Technology in Szczecin located on the premises of the Dolna Odra Power Plant in Nowe Czarnowo. C. carpio $\times$ C. auratus hybrids were reared in PVC-framed fish cages measuring $1.9 \times 1.5$ $\times 1.3 \mathrm{~m}$, with a working volume of $3.2 \mathrm{~m}^{3}$. The fish cages were made of $6 \mathrm{~mm}$ nylon mesh netting mounted on a frame made of PVC tubes $50 \mathrm{~mm}$ in diameter. The cages were placed on a self-supporting pier in a canal approximately $250 \mathrm{~m}$ from the power plant spent cooling water discharge site (Fig. 1).

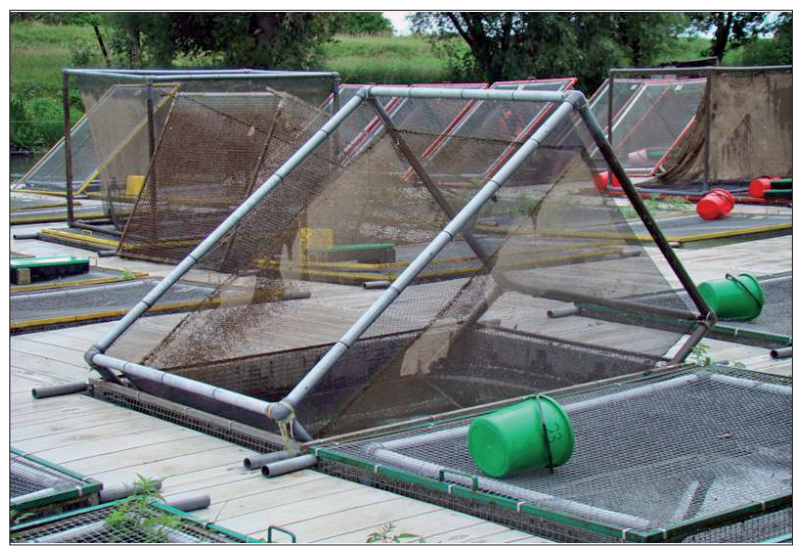

Figure 1. Setup of the cages used in the experiment.

The $C$. carpio $\times$ C. auratus hybrid (Fig. 2 ) rearing material was spring fry of an average mass of $30 \mathrm{~g}$ and a total number of 2,250 individuals that were kept in the cages at a density of 150 ind. cage ${ }^{-1}$. The fry originated from spawning conducted in the RSD in 2009. Five experimental variants were conducted, each in three replicates, with different metabolic feed rations (Table 1). The fish were fed by hand with 2 to 6 portions that were approximately $0.4 \%$ of the metabolic body mass of the fish. The fish were fed at 


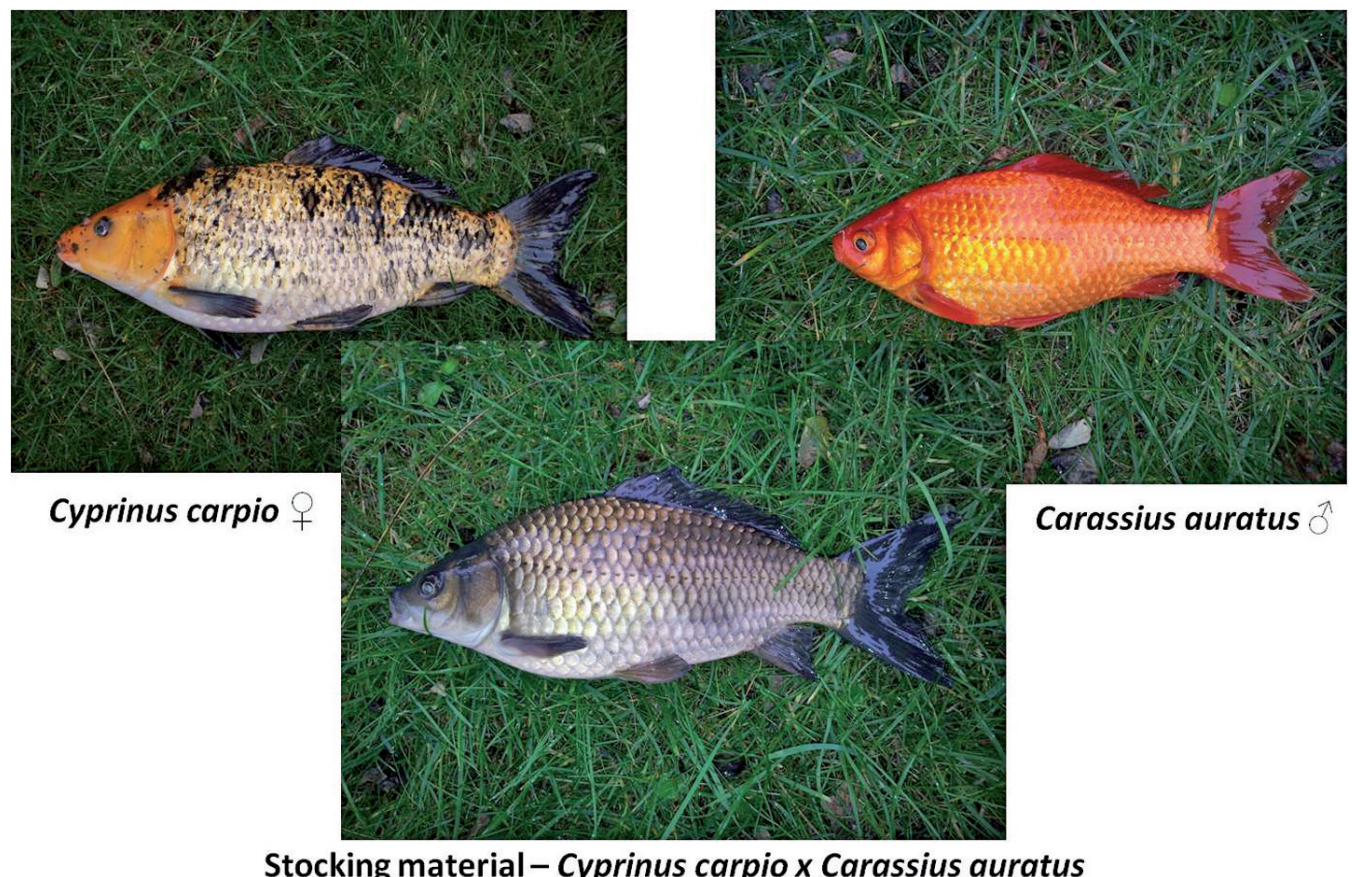

Figure 2. Stocking and parental material used in the experiment.

intervals of 2 hours beginning at 09:00 until the whole feed ration had been delivered. The fish were fed the commercial feed Classic (5 $\mathrm{mm}$ pellet size) produced by Aller Aqua. The proximate composition of the feed is presented in Table 2 .

All the fish in each cage were weighed every 7 days to the nearest $0.05 \mathrm{~kg}$ to determine the required feed rations. The daily feed rations were calculated with the following formula (Sadowski 1998):

$$
F l=M F R \cdot \frac{w_{j}^{0.8}}{w_{j}}
$$

where:

FL - daily feed ration multiplied by the $\%$ of fish weight;

MFR - metabolic feed ration in \%;

$\mathrm{W}_{\mathrm{j}}$ - average individual fish weight in $\mathrm{kg}$.

The results were used to calculate the FCR (Food Conversion Ratio), SGR (Specific Growth Rate), and MGR (Metabolic Growth Rate).

The proximate composition of whole fish bodies and fillets was analyzed in the laboratory of the Department of Aquaculture, West Pomeranian
University of Technology in Szczecin (Table 3). Three whole specimens and six fillets were collected before (from the total number of fish) and after (from each experiment variant) the experiment. The percentages of the following components in the fillets and fish bodies were determined: dry mass by drying samples at $105^{\circ} \mathrm{C}$; ash by burning samples at $550^{\circ} \mathrm{C}$; crude protein with the Kjeldahl method in a Kjeltec 1026 system; lipids with the Soxhlet extraction method with diethyl ether (extraction time -5 hours) (AOAC 2003).

The proximate composition of the feed was determined in $0.5 \mathrm{~kg}$ samples. The same components were determined as in the fish bodies and fillets in three replicates. The gross energy value of the feed was calculated based on its components with the following conversion rates: $39.53 \mathrm{~kJ} \cdot \mathrm{g}^{-1}$ for lipids, $23.63 \mathrm{~kJ} \cdot \mathrm{g}^{-1}$ for crude protein, and $17.15 \mathrm{~kJ} \cdot \mathrm{g}^{-1}$ for carbohydrates (Jobling 1994).

The slaughter yield of the fish was determined with 10 specimens selected at random from each experimental variant that were subjected to preliminary processing by hand, which consisted of producing two pieces (fillets) of fish meat by cutting around the 
Table 3

Results of experiment - proximate analysis of the fish (\% wet weight) and slaughter yield (\%)

\begin{tabular}{|c|c|c|c|c|c|c|c|}
\hline \multirow[b]{2}{*}{ Variants } & \multirow[b]{2}{*}{ Dry matter } & \multicolumn{2}{|l|}{ Lipids } & \multicolumn{2}{|c|}{ Crude protein } & \multirow[b]{2}{*}{ Ash } & \multirow{2}{*}{$\begin{array}{l}\text { Slaughter } \\
\text { yield }\end{array}$} \\
\hline & & Fillet & Whole fish & Fillet & Whole fish & & \\
\hline Start of the experiment & 30.21 & & $15.39^{b}$ & & $13.41^{\mathrm{d}}$ & 1.56 & \\
\hline \multicolumn{8}{|l|}{ End of the experiment } \\
\hline $\mathrm{CC} 1$ & 25.48 & $3.91^{\mathrm{e}}$ & $9.77^{\mathrm{e}}$ & $18.66^{\mathrm{a}}$ & $14.24^{\mathrm{c}}$ & 1.87 & $47.0^{\mathrm{a}}$ \\
\hline $\mathrm{CC} 2$ & 26.14 & $6.22^{\mathrm{d}}$ & $9.76^{\mathrm{e}}$ & $17.88^{\mathrm{b}}$ & $14.16^{\mathrm{c}}$ & 1.3 & $48.7^{\mathrm{a}}$ \\
\hline CC3 & 27.57 & $8.64^{\mathrm{b}}$ & $11.87^{\mathrm{c}}$ & $17.67^{\mathrm{c}}$ & $14.57^{\mathrm{a}}$ & 1.14 & $50.4^{\mathrm{a}}$ \\
\hline $\mathrm{CC} 4$ & 31.66 & $12.32^{\mathrm{a}}$ & $15.91^{\mathrm{a}}$ & $18.62^{\mathrm{a}}$ & $14.43^{\mathrm{b}}$ & 1.07 & $52.0^{\mathrm{a}}$ \\
\hline CC5 & 33.38 & $8.07^{\mathrm{c}}$ & $10.22^{\mathrm{d}}$ & $17.62^{\mathrm{C}}$ & $14.24^{\mathrm{c}}$ & 1.16 & $52.2^{\mathrm{a}}$ \\
\hline MSE & - & 0.03 & 0.04 & 0.04 & 0.03 & - & 4.68 \\
\hline
\end{tabular}

Results in columns with the same letter indexes do not differ significantly $(\mathrm{P}<0.05)$

gills and leaving the pectoral girdle on the head of the fish. The percentage of the total fish weight of the pieces thus prepared was calculated.

The results obtained for the indicators mentioned above and the proximate composition of the feed and fish bodies were analyzed. One-way analysis of variance and LSD testing were performed to determine the statistical significance of means at $\mathrm{P} \leq$ 0.05 (Snedecor and Cochran 1989). The results were processed statistically with Statistica 13.1, a statistics and analytics software package developed by StatSoft (2018). The absence of significant differences among results in respective columns is indicated by the same letter indexes. Additionally, the mean square error (MSE) is presented in the table for all the indicators that were calculated.

Segmented linear regression (Seber and Wild 2003) was performed with Statistica 9.1 to determine the optimal feed ration, as follows:

$$
Y=(b 01+b 11 x) I+(b 02+b 12 x) J
$$

where :

$\mathrm{Y}$ - estimated value of the dependent variable (MGR rate);

b0 - breakpoint value;

b01, b02, b11, b12 regression constants;

$\mathrm{x}$ - independent variable (metabolic feed ration).

$\mathrm{I}=0$ for $\mathrm{y}>\mathrm{b} 0$; $\mathrm{I}=1$ for $\mathrm{y} \leq \mathrm{b} 0$

$\mathrm{J}=0$ for $\mathrm{y} \leq \mathrm{b} 0 ; \mathrm{J}=1$ for $\mathrm{y}>\mathrm{b} 0$

\section{Results}

The results of the attempt to determine the chemical components of the studied feed are presented in Table 2 . The feed comprised fishmeal and fish oil, rapeseed cake, soybeans, blood meal, and wheat.

During the experiment, the average water temperature in the location of the fish cages was $25.9^{\circ} \mathrm{C}$, while the minimum and maximum temperatures were $17.1^{\circ} \mathrm{C}$ and $34.3^{\circ} \mathrm{C}$, respectively. Throughout the study the average daily oxygen content was 7.2 $\mathrm{mg} \cdot \mathrm{dm}^{-3}$, whereas extreme values were $2.8 \mathrm{mg} \cdot \mathrm{dm}^{-3}$ and $12.6 \mathrm{mg} \cdot \mathrm{dm}^{-3}$. The average daily $\mathrm{pH}$ value during the experiment was 7.9 , while the extreme values were 7.5 and 9.0 .

The results of chemical analyses are presented in Table 3, and the values of performance indicators are presented in Table 4. Taking into account all performance indicators, the best rearing results were obtained with the feed ration of $1.6 \%$ of metabolic mass (based mainly on the comparison of FCR and MGR). Similar results were obtained from an evaluation based on a mathematical model, which indicated the estimated optimal ration was $1.4 \%$ of the metabolic weight. The following mathematical model was developed based on statistical analysis:

$$
\mathrm{Y}=(1.286352+5.362726 \mathrm{X}) \mathrm{I}+(9.164009+
$$
$0.518295 \mathrm{X}) \mathrm{J}$. The breakpoint value, equal to 8.78 $\mathrm{g} \cdot \mathrm{kg}^{0.8} \cdot \mathrm{day}^{-1}$, was determined for value $\mathrm{X}=1.4 \%$, while $\mathrm{R}=0.99555$. 
Table 4

Final results of rearing fish (average of three replicates)

\begin{tabular}{|c|c|c|c|c|c|c|c|c|c|}
\hline \multirow[b]{2}{*}{ Variant } & \multicolumn{2}{|c|}{$\begin{array}{l}\text { Mean ibody weight } \\
\text { (g) }\end{array}$} & \multirow{2}{*}{$\begin{array}{l}\text { MGR } \\
\left(\mathrm{g} \cdot \mathrm{kg}^{0.8} \cdot \mathrm{day}^{-1}\right)\end{array}$} & \multirow[b]{2}{*}{ SGR (\%) } & \multirow[b]{2}{*}{ FCR } & \multirow[b]{2}{*}{ aNPU (\%) } & \multirow[b]{2}{*}{ aLR (\%) } & \multirow[b]{2}{*}{ ER (\%) } & \multirow[b]{2}{*}{ Surviva } \\
\hline & Initial & Final & & & & & & & \\
\hline CC1 & 30 & $150 z ̌ z$ & $5.57^{\mathrm{c}}$ & $2.54^{\mathrm{d}}$ & $1.44^{\mathrm{d}}$ & $32.93^{\mathrm{a}}$ & $66.21^{\mathrm{c}}$ & $24.83^{b}$ & 99.3 \\
\hline $\mathrm{CC} 2$ & 31 & 236 & $7.72^{b}$ & $3.21^{\mathrm{c}}$ & $1.55^{\mathrm{c}}$ & $30.02^{b}$ & $65.22^{\mathrm{c}}$ & $23.53^{\mathrm{c}}$ & 99.7 \\
\hline CC3 & 30 & 345 & $9.91^{\mathrm{a}}$ & $3.86^{\mathrm{b}}$ & $1.61^{\mathrm{c}}$ & $29.75^{b}$ & $80.99^{b}$ & $26.33^{\mathrm{a}}$ & 99.1 \\
\hline $\mathrm{CC} 4$ & 32 & 413 & $10.36^{\mathrm{a}}$ & $4.08^{\mathrm{a}}$ & $1.93^{\mathrm{b}}$ & $24.58^{\mathrm{C}}$ & $94.07^{\mathrm{a}}$ & $26.76^{\mathrm{a}}$ & 99.5 \\
\hline CC5 & 30 & 430 & $10.32^{\mathrm{a}}$ & $4.2^{\mathrm{a}}$ & $2.32^{\mathrm{a}}$ & $20.12^{d}$ & $48.13^{d}$ & $16.59^{d}$ & 99.7 \\
\hline MSE & - & - & 0.03 & 0.01 & 0.01 & 0.83 & 3.52 & 0.47 & - \\
\hline
\end{tabular}

Results in columns with the same letter indexes do not differ significantly $(\mathrm{P}<0.05)$

MGR - food ration expressed in $\mathrm{g} / \mathrm{kg}^{0.8}$ divided by FCR

SGR - $100 \times$ (ln Final weight of fish - ln Initial weight of fish) divided by experiment duration (in days)

FCR - total food ration per unit of fish weight gain

aNPU - amount of crude protein retained per unit of crude protein intake x 100

aLR - amount of lipid retained per unit of lipid intake x 100

ER - amount of gross energy retained per unit of gross energy intake x 100

Only individual fish deaths were noted during the experiment (11 individuals in total); dead specimens were replaced with spare material (fish of the same weight that had been fed in the same way, and that had been tagged). Survival rates in the different experimental variants were $0.8 \%(99.3 \%), 1.2 \%$ (99.7\%), $1.6 \%$ (99.1\%), $2.0 \%(99.5 \%)$, and $2.4 \%$ (99.7\%).

The results of studying the slaughter yield revealed that there were no statistically significant differences among the applied feed rations even though, as far as the absolute values were concerned, the difference between the lowest value noted for variant $\mathrm{CC} 1$ and the highest value noted for variant CC5 was as much as $5.2 \%$ (Table 3 ).

\section{Discussion}

The temperature of spent cooling water is usually higher than that of water in the natural environment. During summer, the temperature of spent cooling water exceeds the optimal temperature range for fish from the family Cyprinidae. The other physicochemical indicators of spent cooling water are within the limits that most authors believe to be optimal for representatives of Cyprinidae. Thus, it can be assumed that values of the basic physicochemical water parameters did not have a serious impact on the results of rearing in the experiment.

Ensuring that feed provides the quantitative demand for basic nutritional ingredients is a fundamental condition for guaranteeing successful fish rearing. Facilitating fast fish growth rates when using a relatively small quantity of feed depends on a number of factors directly connected with the applied feeding method. In the present study, only one kind of feed was used, but the feed rations used in the experimental variants differed. Obviously the different feed rations did not meet the nutritional and energetic needs of the fish subjected to the experiment to the same degree. According to the growth rate indicators (MGR and SGR), the best results were obtained in variants CC3 and CC4 (Table 4), while the values of these indicators for the other feed rations were lower and significantly different. The feed used in the experiment was one that had yielded good results for many years with carp in both pond and intense cage rearing. The protein content of the feed used in the experiment was $30.59 \%$. According to Filipiak and Trzebiatowski (1992), a 30\% protein content is 
optimal for intensely rearing carp in spent cooling water. Thus, it can be concluded that the protein level in the feed was appropriate. In an earlier experiment in which various types of commercial feed was used, it was discovered that Classic carp feed met the nutritional needs of the $C$. carpio $\times C$. auratus. hybrid (Sadowski et al. 2009). Applying feeds with higher protein and energy contents did not yield better rearing results, but it did increase the cost of the undertaking (Sadowski et al. 2009).

The analysis of the nutritional coefficients values obtained indicated that these values decreased as feed ration quantity increased, which is typical for this kind of experiment. However, the analysis of the results of growth rates measured with MGR and nutritional coefficients indicated that the best rearing results were obtained when the metabolic feed ration was $1.6 \%$ of metabolic mass (Table 4 ). In comparison, when the same feed is applied to feed carp reared under the same environmental conditions, $25 \%$ higher feed rations are usually applied, which is $2.0 \%$ of metabolic mass.

An important element of the experiment was evaluating to what degree the fish utilized the nutritional components of the feed. This was analyzed using the retention factors of gross energy retention (ER), apparent net protein utilization (aNPU), and lipid retention (aLR). In variant CC4 (2.0\%), the ER value was the highest at $27.25 \%$, whereas in variant CC5 (2.4\%) it was the lowest at $16.47 \%$. Apparent net protein utilization (aNPU) was the highest in variant $\mathrm{CC} 1(0.8 \%)$ at $32.93 \%$, and it was the lowest in variant CC5 (2.4\%) at $20.12 \%$. The highest value of the lipid retention coefficient was obtained in variant CC1 $(0.8 \%)$ at $66.21 \%$, while the lowest value was obtained in variant CC5 (2.4\%) at 48.13\%. The analysis of apparent net protein utilization (aNPU) values revealed no statistically significant differences between variants CC2 and CC3 when different metabolic feed rations were applied. Moreover, the difference between variants CC1 and CC2 was only slight. However, the considerable difference in growth rates indicated that variant CC3 $(1.6 \%)$ was the most advantageous one in terms of feed protein utilization. The best accumulation of energy from the feed in the bodies of the fish hybrid studied measured with the ER indicator was noted in variants CC3 (1.6\%) and CC4 (2.0\%), but there were no statistically significant differences.

The analysis of the proximate composition of fish bodies revealed that in all variants the overall protein content increased in comparison to initial values (Table 3). The highest differences were noted in the raw fat content of the fish bodies. The highest lipid content in whole fish bodies was noted in variant CC4 $(2.0 \%)$ at $15.91 \%$, which differed significantly from that in the other variants. Moreover, the fillet lipid content was the highest in this variant (CC4) at $12.32 \%$.

Another method for determining optimal feed rations is to use a mathematical model, and one of the more popular ones is the sigmoidal curve model (Robbins et al., 1979). Other popular models include the polynomial curve and broken-line analysis (Zeitoun et al. 1976). In the present study, using the segmented linear regression model (which is similar to broken-line analysis) allowed us to obtain a high regression value. Based on this model, the optimal feed ration was determined to be $1.4 \%$, which was close to that determined by analyzing rearing results (1.6\%).

According to Bartley et al. (2001), creating interspecific hybrids can serve to, inter alia, accelerate growth rates, manipulate sex ratios, produce infertile individuals, and increase immunity to diseases. This last aim was the crucial one with the present hybrid, which was introduced to limit outbreaks of the viral disease caused by the Cy-HV3 virus. Since the growth potential of goldfish is definitely lower compared to carp, the hybrid was not expected to achieve higher or even comparable growth rates. However, it was assumed that well-adjusted feed rations would permit obtaining nutritional coefficient values that would be comparable to those of carp. Aller Aqua Classic feed was chosen since it yielded good rearing results in previous experiments with the $C$. carpio $\times$ C. auratus hybrid (Sadowski et al. 2009). The rearing results obtained during the present experiment indicated that even in the best variant the performance indicators 
measured with the nutritional coefficient and growth rate were still worse in comparison to those of carp (Omar and Gunther 1987a, 1987b, 1987c, Sadowski 1998). The available literature provides no data on rearing this hybrid in environmental conditions other than spent cooling water; thus the results cannot be discussed in the context of other studies. However, a comparison of the current results with those obtained for carp (Sadowski 1998) indicated that the $C$. carpio $\times C$. auratus hybrid has much lower growth potential than carp. Nevertheless, it was still possible to raise fish in spent cooling water that achieved commercial weights of approximately $500 \mathrm{~g} \cdot$ indiv. $^{1}$ in the second year of rearing. The commercial value of the C. carpio $\times$ C. auratus hybrid is limited by its considerable number of bones and complete scale cover. However, taking into account the comparatively high slaughter yield of the hybrid (Table 4), it is possible that the hybrid can become important in countries where scale fish are accepted and the epizootic KHV caused by the $\mathrm{Cy}-\mathrm{HV} 3$ virus is a threat. An additional asset of the hybrid is the fact that it occurs relatively easily in natural conditions (Pullan and Smith 1987).

In summation, the results of the experiment showed that the segmented linear regression model permitted determining that the optimal metabolic feed dose was $1.4 \%$. The rearing results and chemical analyses indicated that the most advantageous of the applied feed doses in the experiment was that of $1.6 \%$. Unfortunately, in comparison with carp, this meant that growth rates were at least a $25 \%$ lower, which prolonged the production cycle.

Author contributions. The co-authors contributed in similar proportions to the work; the main author J.S. developed the concept and methodology.

\section{References}

AOAC 2003 - Association of official analytical chemists - In: Official Methods of Analysis. $17^{\text {th }}$ ed. Gaithersburg.

Bartley D.M., Rana K., Immink A.J. 2001 - The use of inter-specific hybrids in aquaculture and fisheries - Rev. Fish Biol. Fish. 10: 325-337.
Bergmann S.M., Sadowski J., Kiełpiński M., Bartłomiejczyk M., Fichtner D., Riebe R., Lenk M., Kempter J. 2010 Susceptibility of koi $\times$ crucian carp and koi $\times$ goldfish hybrids to koi herpesvirus (KHV) and the development of koi herpesvirus disease (KHVD) - J. Fish Dis. 33: 267-272.

Bergmann S.M., Kempter J., Sadowski J., Fichtner D. 2006 First detection, confirmation and isolation of koi herpesvirus (KHV) in cultured common carp (Cyprinus carpio L.) in Poland - Bull. Eur. Ass. Fish Pathol. 26: 97-104.

Filipiak J., Trzebiatowski R. 1992 - Determining optimum protein requirements for carp of different sizes $\left(\mathrm{K}_{1-2}\right)$ reared in spent cooling water - Zesz. Nauk. AR Wrocław, Zoot. 37 (218): 61-71 (in Polish)

Filipiak J., Sadowski J., Trzebiatowski R. 1995 - Comparison of the effects of cage rearing of african catfish (Clarias gariepinus) and nile tilapia (Oreochromis nilotica) in cooling water - Arch. Pol. Fish. 3 : 95-105.

Filipiak J., Sadowski J., Trzebiatowski R. 1997a - Impact of metabolic food rations on results of rearing of 2-year-old European catfish (Silurus glanis L.) in cooling water Zesz. Nauk. AR Szczecin 179 (23): 15-26.

Filipiak J., Sadowski J., Trzebiatowski R. 1997b - Comparative analysis of results of using different food rations in juvenile wels (Silurus glanis) culture - Acta Ichthyol. Piscat. 27: 41-51.

Filipiak J., Sadowski J., Trzebiatowski R. 1997c - Feeding of the Siberian Sturgeon (Acipenser baeri) with different commercial feeds in cooling water - Zesz. Nauk. AR Szczecin 179 (23): 5-13.

Filipiak J., Sadowski J., Trzebiatowski R. 1998a - Comparing results of carp (Cyprinus carpio L.) and wells (Silurus glanis L.) cultures involving different metabolic food rations - Folia Univ. Agric. Stetin. Piscaria 24: 15-23.

Filipiak J., Sadowski J., Trzebiatowski R. 1998b - Determination of utility of selected commercial feeds in carp rearing - Folia Univ. Agric. Stetin. Piscaria 24: 5-13.

Filipiak J., Przybył A., Sadowski J., Plust M., Trzebiatowski R. 1998c - Effects of different dietary lipid levels in extruded food on the growth of $1+$ old carp (Cyprinus carpio) cultured in cooling water - Acta Ichthyol. Piscat. 28: 27-37.

Hedrick R.P., Waltzek T.B., McDowell T.B. 2006 - Susceptibility of Koi Carp, Common Carp, Goldfish, and Goldfish $\times$ Common Carp Hybrids to Cyprinid Herpesvirus-2 and Herpesvirus-3 - J. Aquat. Anim. Health. 18: 26-34

Jobling M. 1994 - Fish bioenergetics - Chapman \& Hall, London.

Omar B.A., Günther K.D. 1987a - Studies on feeding of mirror carp (Cyprinus carpio L.) in intensive aquaculture. 1. Effect of type of feed and level of feeding - J. Anim. Physiol. Anim. Nutr. 57: 67-74. 
Omar B.A., Günther K.D. 1987b - Studies on feeding of mirror carp (Cyprinus carpio L.) in intensive aquaculture. 2 . Effect of frequency and increased levels of feeding - J. Anim. Physiol. Anim. Nutr. 57: 172-180.

Omar B.A., Günther K.D. 1987c - The optimum feeding levels for growing of mirror carp (Cyprinus carpio L.) in intensive culture - J. Anim. Physiol. Anim. Nutr. 57: 180-190.

Pullan S., Smith P.J. 1987 - Identification hybrids between koi (Cyprinus carpio) and goldfish (Carassius auratus) New Zeal. J. Mar. Freshw. Res. 21: 42-46.

Robbins K.R., Norton H.W., Baker D.H. 1979 - Estimation of nutrient requirements from growth data - J. Nutr. 109: 1710-1714.

Sadowski J. 1998 - Impact of metabolic feed doses on selected rearing indicators of fish reared in spent cooling waters - PhD thesis, AR Szczecin (in Polish).

Sadowski J., Filipiak J., Trzebiatowski R. 1998 - Effect of different duration of feeding on result of carp (Cyprinus carpio) fry cage culture in cooling water - EJPAU 1(1): \#2, http://www.ejpau.media.pl/volume1/issue1/fisheries/art-02.html.

Sadowski J., Filipiak J., Trzebiatowski R., Plust M. 1999a A comparative study on results of feeding different commercial feeds to carp kept in cooling water - Folia Univ. Agric. Stetin. Piscaria 25: 63-70.

Sadowski J., Filipiak J., Trzebiatowski R., Plust M. 1999b Preliminary studies on effects of diet enrichment with propiscin, bio-immuno, and ascrobyl sulphate on cage culture of carp (Cyprinus carpio L.) juveniles in cooling water - Folia Univ. Agric. Stetin. Piscaria 25: 71-77.
Sadowski J., Trzebiatowski R., Odebralska D., Wielopolska M. 2000a - Preliminary studies on optimisation of feed rations for Siberian sturgeon (Acipenser baeri) kept in cooling water - Folia Univ. Agric. Stetin. Piscaria 26: 57-62.

Sadowski J., Trzebiatowski R., Wielopolska M. 2000b Growth rate comparisons between sterlet (Acipenser ruthenus) and Russian sturgeon (Acipenser gueldenstaedti) x Siberian sturgeon (Acipenser baeri) hybrid in heated water culture - Folia Univ. Agric. Stetin. Piscaria 26: 63-70.

Sadowski J., Wielopolska M., Bartłomiejczyk M. 2009 Impact of selected Aller-Aqua commercial feeds on the growth and proximate composition of Cyprinus carpio $x$ Carassius auratus hybrids reared in spent cooling waters - In: Breeding and rearing of and prophylactics for salmonids and other species (Eds) Z. Zakęś, K. Demska-Zakęś, A. Kowalska, D. Ulikowski, Wyd. IRS, Olsztyn : 273-279 (in Polish).

Snedecor G.W., Cochran W.H. 1989 - Statistical Methods Iowa State Univ. Press, Ames, 503 p.

StatSoft Inc. 2018 - Statistica (data analysis software system), version 13.1 - www.statsoft.com.

Seber G.A.F., Wild C.J. 2003 - Nonlinear regression - John Wiley \& Sons, Hoboken, New York, USA. 768 p.

Trzebiatowski R., Filipiak J., Jakubowski R. 1981 - Effect of stock density on growth and survival of rainbow trout (Salmo gairdneri Rich.) - Aquaculture 22: 289-295.

Zeitoun I. H., Ullrey D. E., Magee W. T., Gill J. L., Bergen W. G. 1976 - Quantifying nutrient requirements of fish - J. Fish. Res. Bd. Canada 33: 167-172. 